\title{
CHEMICAL ANALYSIS OF CERTAIN CONSTITUENTS OF THREE PREY SPECIES OF THE PREDATOR, CRYPTOLAEMUS MONTROUZIERI
}

\author{
AFIFI, AMAL I. ${ }^{1}$, ANGEL R. ATTIA ${ }^{2}$, S. A. EL ARNAOUTY ${ }^{1}$ and \\ ASMAA EL- METWALLY ABD ALLA ${ }^{1}$ \\ 1. Department of Economic Entomology and Pesticides, Faculty of Agriculture, Cairo \\ University, Giza, Egypt. \\ 2. Plant Protection Research Institute, ARC, Giza, Egypt.
}

(Manuscript received 4 June 2012)

\begin{abstract}
The predator, Cryptolaemus montrouzieri Mulsant, (Coleoptera: Coccinellidae) is an important predator of mealybugs (Hemiptera: Pseudococcidae). It may be fairly, considered a valuable biocontrol agent against mealybugs because other biological control methods proved ineffective due to the waxy coat that covers insect body in addition to its feeding habits. To shed light on the effect of the chemical constituents of a prey on the biology of its predator, certain chemical analyses were carried out on the tested preys to estimate the protein, carbohydrate, lipids, sodium, potassium, and calcium contents. The present work dealt with the host preference of the predator, $C$. montrouzieri by using chemical analysis of certain constituents (protein, carbohydrates, lipids, calcium, sodium together with the Potassium) of Planococcus citri(Risso) (Hemiptera : Pseudococcidae) eggs, Ephestia kuehniella Zeller (Lepidoptera: Pyralidae) eggs and Schizaphis graminum (Rondani) ( Hemiptera: Aphididae) nymphs. Chemical analysis of certain constituents of the tested preys of the predator C. montrouzieri showed that $P$. citri eggs had the highest total carbohydrates $(31.37 \mathrm{mg} / \mathrm{g})$, total lipids $(8.81 \mathrm{mg} / \mathrm{g})$ and potassium content $(1.3179 / \mathrm{mg})$, compared to the other two prey species ( $E$. kuhniella eggs and $S$. graminum nymphs). It could be finally concluded that the greatest constituents of carbohydrates, lipids and potassium in eggs of $P$. citri are mostly, the reason of its suitability for rearing the predator $C$. montrouzieri.
\end{abstract}

\section{INTRODUCTION}

Biological control with the coccinellid predator, Cryptolaemus montrouzieri Mulsant (Coleoptera: Coccinellidae) proved very successful in suppressing populations of the mealybugs (Hemiptera : Pseudococcidae) . A single predator can consume 900-1500 eggs or 300 nymphs of the mealybug Maconellicoccus hirsutus (Green) (Hemiptera : Pseudococcidae) during its development. This coccinellid could be reared in large numbers on M. hirsutus infesting pumpkin fruits. Releases of 1000-1500 predator adults /acre gave effective control within 2 months (Mani, 1988). 
Baskaran et. al. (1999), studied the biology and predation of C. montrouzieri (at $29.4-32.1^{\circ} \mathrm{C}$ and $65-71 \% \mathrm{RH}$. ) in association with two types of prey [Planococcus citri (Risso) (Hemiptera : Pseudococcidae) and Dactylopius tomentosus (Lamarck) (Hemiptera: Dactylopiidae)]. They found that $C$. montrouzieri Mulsant completed the development successfully with both prey species, but preferred $P$. citri to $D$. tomentosus. Feeding preference by $C$. montrouzieri on $P$. citri was twice that with $D$. tomentosus (150.83 and $72 \mathrm{mg}$, respectively).

Prabal and Balasubramanian (2000) found that, the larva of C. montrouzieri period was prolonged when reared on nymphs of aphids compared to mealybug nymphs. The larval period of $C$. montrouzieri was completed in 21.20, 20.00, 23.20 and 13.92 days when reared on Aphis gossypii Glover (Hemiptera: Aphididae) on cotton, okra, cowpea aphid and mealybugs, respectively.

Abd Alla (2011) found that, the adult of C. montrouzieri fed on average of $246 \pm$ 13.09 eggs of $P$. citri, $132 \pm 6.63$ eggs of Ephestia Kuehniella Zeller (Lepidoptera: Pyralidae), $7.9 \pm 0.65$ nymphs of $P$. citri or $5.8 \pm 0.74$ nymphs of Schizaphis graminum (Rondani) ( Hemiptera: Aphididae). S. graminum. The order of predatory preference of adult predator on different prey species was P.citri eggs $(61.85 \pm 0.01 \%)>$ E. kuehniella eggs $(33.66 \pm 0.01 \%)>P$. citri nymphs $(2.06 \%)>S$. graminum nymphs (1.54\%). Therefore, it is quite safe to state that eggs of $P$. citri were the most preferable prey for $C$. montrouzieri, and the nymphs of $S$. graminum were the least preferred.

The aim of the present work was to study the prey preference of the predator, $C$. montrouzi relation to the chemical constituents (protein, carbohydrates, lipids, calcium, sodium together with the Potassium) in three prey species (P.citri eggs, $E$. kuehniella eggs and S. graminum nymphs).

\section{MATERIALS AND METHODS}

\section{Rearing of prey species}

\section{a. Mealybug, Planococcus citri}

The prey was obtained from infested croton ornamental plants, Codiaeum variegatum (L.) at Giza region and reared on pumpkin fruits under laboratory conditions (27 $\pm 2{ }^{\circ} \mathrm{C}$ and $60-70 \%$ R.H.) in the Chrysoperla carnea (Stephens) (Neuroptera: Chrysopidae) mass production laboratory, Faculty of Agriculture, Cairo University. The pumpkins were selected with ridges, grooves and with a small stalk which makes handling very easy.Fruits were cleaned with running water to get rid of dust. Ovisacs of the mealybug were placed over the pumpkin for about 48 hours. 
Infested pumpkins were kept on a plastic stand in wooden cages, with glass sliding front and cloth on other sides. After emergence from ovisacs, crawlers settled on all sides of fruits and developed into fully mature mealybugs in 30-40days. This technique of propagating mealybug culture on pumpkin fruits has been standardized by Chacko et. al. (1978) and Singh (1978).

\section{b. Ephestia kuehniella}

Eggs of E. kuehniella were obtained from the stock culture of Chrysopa Mass Rearing Unit, Faculty of Agriculture, Cairo University. The pyralid, E. kuehniella was mass reared at $23^{\circ} \mathrm{C}$. Batches of 900 eggs were distributed upon the rearing tray containing crushed wheat. Rearing started in the laboratory at $23^{\circ} \mathrm{C}$ for 30 days, then at $10^{\circ} \mathrm{C}$ for 30 days and at $23^{\circ} \mathrm{C}$ for the last 5 days until moths'emergence. Newly emerged adults were collected daily, knocking them down by passing carbondioxide gas. The recovery was quite rapid and allowed to put adults in reproduction cylinder. Eggs produced by this colony of adults were divided into two groups, one group used for maintaining the colony, and the other as food supply for the predator.

\section{c. Schizaphis graminum}

Nymphs of S. graminum were obtained from the stock culture of "Chrysopa Mass Rearing Unit", Faculty of Agriculture, Cairo University. Rearing was carried out in chambers conditioned at $19^{\circ} \mathrm{C}$ and $16 \mathrm{~h}$ light/day. Wheat seedlings were grown in Plexiglas boxes $(30 \times 13 \times 10 \mathrm{~cm})$ containing humid pine tree sawdust (previously soaked in water for 24 hours). The use of pine tree sawdust previously soaked was to avoid fermentation of material that could inhibit wheat growth. The humid sawdust was placed and compacted to half the height of the box so as to provide the future plants with an adequate substrate for rooting, the remaining area of the box was covered with a non compacted layer of wet sawdust to facilitate germination of seeds and penetration of seedlings. For germination, dry seeds were placed in water for 24 hours under the laboratory conditions mentioned above and then planted between the two sawdust layers. The boxes were kept at $19^{\circ} \mathrm{C}$ and germination occurred one week after seeding. When the young plants reached $2 \mathrm{~cm}$ hight, those were artificially infested with aphids through cut offs. Graminum infested of older green pea plants.. One box from the colony allowed infestation of 2 to 2.5 new boxes that were then placed in muslin cages to prevent any other infestation.

\section{Chemical analysis}

The prey's contents of protein, carbohydrates, lipids, calcium, sodium and potassium were analyzed as follows:

1- Total soluble proteins ( $\mathrm{mg} / \mathrm{g}$ body weight): determined by the method of Bradford (1976). 
2- Total soluble carbohydrates ( $\mathrm{mg} / \mathrm{g}$ body weight): determined by the method previously followed by Singh and Sinha (1977).

3- Total soluble lipids (mg/g body weight): estimated according to Knight et. al. (1972), by using phosphor aniline reagent.

4- Calcium, Sodium and Potassium contents: Samples were digested using advanced microwave digestion system. ETHOS1and the measurement on the device ICP Spectrometer (ICAP 600 series, Thermo Scientific.)

\section{Statistical analysis}

Data were analyzed by multivariable analysis (ANOVA) using Mstat-C program. When significant differences $(P<0.05)$ were calculated, the least significant difference (LSD) test was used to separate the mean values according to Steel and Torrie (1981).

\section{RESULTS AND DISCUSSION}

Data revealed that $E$. kuehnielle eggs contained the greatest total amount of protein $(8.7 \mathrm{mg} / \mathrm{g})$, followed by $P$. citri eggs $(7.69 \mathrm{mg} / \mathrm{g})$, and lastly by nymphs of $S$. graminum $(4.69 \mathrm{mg} / \mathrm{g})$ (Table 1$)$. Statically, significant deviations existed between the protein contents estimated in the different tested preys while, the highest carbohydrate and lipid contents were estimated in $P$. citri eggs, $(31.37$ and $8.81 \mathrm{mg} . / \mathrm{g}$ body weight), being significantly higher than those in E. kuehniella eggs (6.96 and $3.32 \mathrm{mg} . \mathrm{g}$ ) and also in bodies of S. graminum nymphs (14.75 and $1.22 \mathrm{mg} . / \mathrm{g}$ body weight, respectively) (Table, 1 ).

As for calcium, potassium and sodium contents in the three prey species, those were nonsignificantly defferent in cases of calcium $(0.50,0.458$ and 0.537 $\mathrm{g} / 100 \mathrm{~g}$ body weight of $P$. citri eggs, E. kuehniella eggs and $S$. graminum nymphs, respectively) and sodium $(0.212,0.234$ and $0.424 \mathrm{~g} / 100 \mathrm{~g}$, respectively) the highest potassium content $(1.317 \mathrm{~g} / 100 \mathrm{~g})$ was estimated in $P$. citri eggs, being no significantly higher than that estimated in $E$. kuehniella eggs $(1.034 \mathrm{~g} / 100 \mathrm{~g})$ and significantly higher than that estimated in S. graminum nymphs $(0.738 \mathrm{~g} / 100 \mathrm{~g}$ body weight) (Table, 2).

On basis of the aforementioned data, it could be stated that the greatest constituents of carbohydrates, lipids and potassium in eggs of $P$. citri compared to other tested preys, may be considered as the main reason of its suitability for massrearing of the predator $C$. montrouzieri.

According to data recorded by Attia et al (2011), the eggs of $P$. citri were found the most adequate prey for rearing $C$. montrouzieri predator. In association with this prey, 
adult female deposited the greatest number of eggs (1049.7 eggs/female), coincided with the highest daily rate of reproduction (10.86 eggs / day/female). On this prey, the adult female lived a comparatively longest period (104.5 days), of which 97.9 days was reported as an oviposition period. The larval stage lasted 20.27 days with lowest rate of mortality (6.0\%). By feeding on E. kuehniella eggs, the larval stage lasted a shorter period, (16.70 days). Larval mortality was higher (38.0\%). Females produced lower amount of eggs (695.7eggs/female), throughout a longer oviposition period of 104.4 days. Fewer daily rate of reproduction was reported ( 6.7 eggs/ female). When using $S$. graminum nymphs as a prey, the same authors found that the longevity of adult female was the shortest (45.30 days). Female produced also the smallest amount of eggs (89.50 eggs) throughout the shortest oviposition period (34.30 days).While the larval mortality was the highest (42\%). In the same trend, Oonincx and Dierenfeld (2011) studied the chemical composition of eight invertebrate species and evaluated their suitability as alternative preys. Dry matter (DM), crude protein, crude fat, neutral detergent fiber, acid detergent fiber, ash, macro and trace minerals, vitamins $A$ and $E$, and carotenoid concentrations were quantified. Significant differences were found between species. Crude protein content ranged from 38 to $76 \%$ DM, fat from 14 to $54 \%$ DM, and ash from 2 to $8 \%$ DM. In most species, calcium:phosphorus was low (0.08-0.30:1). Vitamin $E$ content was low for most species (6-16 $\mathrm{mg} / \mathrm{kg} \mathrm{DM})$. The retinol content, as a measure of vitamin A activity, was low in all specimens, but varied greatly among samples $(0.670-886 \mathrm{mg} / \mathrm{kg} \mathrm{DM})$. The data presented can be used to alter diets to better suit the estimated requirements of insectivores in captivity.

Table 1. Proteins, carbohydrates and lipids contents ( $\mathrm{mg} / \mathrm{g}$ body weight) in different tested preys.

\begin{tabular}{|l|l|l|l|}
\hline \multirow{2}{*}{$\begin{array}{l}\text { Chemical } \\
\text { Constituents }\end{array}$} & $\begin{array}{l}\text { P. citri } \\
\text { Eggs }\end{array}$ & $\begin{array}{l}\text { E. kuehniella } \\
\text { eggs }\end{array}$ & $\begin{array}{l}\text { S. graminum } \\
\text { nymphs }\end{array}$ \\
\cline { 2 - 4 } & $7.69 \pm 0.13 \mathrm{~b}$ & $8.70 \pm 0.03 \mathrm{a}$ & $4.69 \pm 0.10 \mathrm{c}$ \\
\hline Total proteins & $31.37 \pm 0.13 \mathrm{a}$ & $6.96 \pm 0.01 \mathrm{c}$ & $14.75 \pm 0.05 \mathrm{~b}$ \\
\hline Total carbohydrates & $8.81 \pm 0.01 \mathrm{a}$ & $3.32 \pm 0.01 \mathrm{~b}$ & $1.22 \pm 0.01 \mathrm{c}$ \\
\hline Total lipids & & & \\
\hline
\end{tabular}

Averages having the same letter in the same row are not significantly different at $0.05 \%$ probability level. 
Table 2. Calcium, potassium and sodium contents $(\mathrm{g} / 100 \mathrm{~g})$ in different tested preys

\begin{tabular}{|l|c|c|c|}
\hline \multirow{2}{*}{\begin{tabular}{l} 
Chemical \\
\cline { 2 - 4 }
\end{tabular}} & P. citri & Preys & \\
\hline Calcium & $0.500 \mathrm{a}$ & $\begin{array}{c}\text { E. kuehniella } \\
\text { eggs }\end{array}$ & $\begin{array}{c}\text { S. graminum } \\
\text { nymphs }\end{array}$ \\
\hline Potassium & $1.317 \mathrm{a}$ & $0.458 \mathrm{a}$ & $0.537 \mathrm{a}$ \\
\hline Sodium & $0.212 \mathrm{a}$ & $1.034 \mathrm{ab}$ & $0.738 \mathrm{~b}$ \\
\hline
\end{tabular}

Averages having the same letter in the same row are not significantly different at $0.05 \%$ probability level.

\section{REFERENCES}

1. Abd Alla, A. E. 2011. Biological studies on the predator, Cryptolaemus montrouzieri Mulsant (Coleoptera: Coccinellidae) . M.Sc. Thesis, Fac. Agric., Cairo University, 139pp.

2. Attia, A. R., Afifi, A. I., El Arnaouty, S. A. and A. E. Abd Alla. 2011. Feeding potential of Cryptolaemus montrouzieri Mulsant on eggs, nymphs and adults of Planococcus ficus and Ephestia kuehniella eggs.

3. Baskaran, R.K.M., Lakshmi, L.G. and S. Uthamasamy. 1999. Comparative biology and predatory potential of Australian ladybird beetle, (Cryptolaemus montrouzieri Mulsant) on Planococcus citri and Dactylopius tomentosus. Entomon., 24(2):173176.

4. Bradford, M.M. 1976. A rapid and sensitive method for the quantization of microgram quantities of protein utilizing the principle of protein-dye binding. Anal. Biochem., 72:248-254.

5. Chacko, M. J., Bhat, P.K., Rao, L.V.A., Singh, M.B.D., Ramanarayan, E.P. and Sreedharan, K., (1978). The use of ladybird beetle, Cryptolaemus montrouzieri for the control of coffee mealybugs. J. Coffee Res., 8:14-19.

6. Knight, J.A., Anderson, S. and J.M. Rawle. 1972. Chemical basis of the sulfophospho-vanillin reaction for estimating total serum lipids. Clin. Chem., 18:199-202.

7. Mani, M. 1988. Bioecology and management of grapevine mealybug. Technical Bulletin Indian Institute of Horticultural Research, (5):32.

8. Oonincx DG. And ES. Dierenfeld. 2011. An investigation into chemical composition of alternative invertebrate prey. Zoo Biol.29: 1 - 15 . 
9. Prabal, S. and A. Balasubramanian. 2000. Feeding potential and larval development of Cryptolaemus montrouzieri Muls. on aphids and mealybug. Journal of the Agricultural Science Society of North East India, 13(1):8-11.

10. Singh, S.P. 1978. Propagation of a Coccinellid beetle for the biological control of citrus and coffee mealybugs. Scientific Conference. CPA. Des., P. 2.

11. Singh, N.B. and R.N. Sinha. 1977. Carbohydrates, lipids and protein in the developmental stages of Sitophillus oryzea and Sitophillus grannarius. Ann. Ent. Soc. Am., pp.107-111.

12. Steel, R. G. D. and J. H. Torrie. 1981. Priniciples and procedures of statistics: A Biometrical Approach. $2^{\text {nd }}$ ed. McGraw Hill Book Co. New York, Ny. 


\section{التحليل الكيميائى للمكونات الأساسية لثلاث أنواع من فرائس المفترس كريبتوليمس مونتروزييرى}

أمال عفيفى 1 أنجيل رشدى عطية2 ، سبد أثرف الأرناؤوطى1 ، أسماء المتولى عبد الله1 ا ـ قسم الحشرات الأقتصادية والمبيد/ت ، كلبة الزراعة - جامعة القاهرة - جيزة - مصر

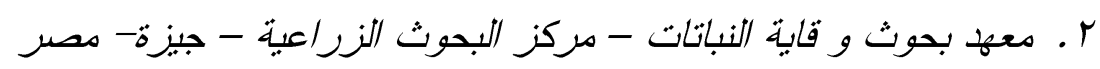

تم إجر اء تحليل كيماوى لثناثة أنو اع من الفرائس المختلفة للمفترس الحشرى كريبتوليمس مونتروزييرى وهى بيض بق الموالح الدقيقى، بيض فراش دقيق البحر المتوسط وحوريات من الغلال لتقدير كية البروتين، الكربو هيدرات، الدهون الصوديوم، الكالسيوم و البوتاسيوم فى مجمع المعامل النوعية بكلية الزر اعة جامعة

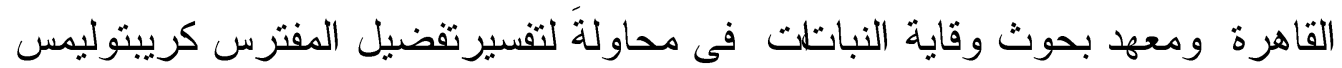
لبيض البق الدقيقى مقارنة بباقى الفرائس . وقد أوضحت التحليلات الكيماوية للفر ائس المستـــخدمة أن بيض البق الدقيقى يحتوى أعلى كمية من الكوبو هيدرات (31.37مجم/جم) ، الدهون(8181 مجم/جم) و البوتاسيوم (100/جم/ (1017 جم) وقد يكون هذا أحد العوامل الأساسية لتفضيل المفترس لهذه الفريسة، مقارنة ببيض فر اش دقيق البحر المتوسط وحوريات من الغلال. 